\title{
IDENTIFIKASI SIFAT KUALITATIF DAN KUANTITATIF SAPI RANCAH
}

\author{
(Identification of Qualitatif and Quantitatif Traits of Rancah Cattle) \\ N. Hilmia ${ }^{1}$, R. R. Noor ${ }^{2}$, C. Sumantri², R. Priyanto ${ }^{2}$, D. Rahmat. ${ }^{1}$ \\ ${ }^{1)}$ Produksi Ternak Fakultas Peternakan Universitas Padjadjaran \\ Jl. Raya Bandung Sumedang Km 21 Jatinangor Sumedang Jawa Barat, Indonesia \\ ${ }^{2)}$ Ilmu Produksi dan Teknologi Peternakan Fakultas Peternakan Institut Pertanian Bogor \\ Jl. Agatis Kampus IPB, Darmaga, Bogor16680 Jawa Barat, Indonesia \\ Email : nena.hilmia@unpad.ac.id
}

Article Submitted : 04-09-2019

Article Accepted : 06-10-2019

\begin{abstract}
Characterization of qualitative and quantitative traits is needed to delve the potential of local cattle as basic information to promote the genetic resources. The research aims to identify qualitative and quantitative traits of Rancah cattle in Ciamis Regency. The samples used were 92 Rancah cows, over 3 years old, 40 heads from Tambaksari sub-district and 52 heads from Cijulang sub-district. The parameters measured were variations in coat color, body weight and body measurements in the two these areas. Data were analyzed descriptively, differences body weight and body size parameter in the two study populations was analyzed by T-Test. The results showed the dominant color of Rancah cattle was brick red. Body weight and body size in Cijulang is greater than Tambaksari, except the length and width head. The body weight and morphometrics of Rancah cattle are between Balinese and PO cattle.
\end{abstract}

Keywords : Qualitatif, quantitative, Rancah cattle

\section{PENDAHULUAN}

Sapi lokal Ciamis, yang lebih dikenal dengan sapi Rancah adalah salah satu sumber daya genetik sapi potong di Jawa Barat yang perlu digali potensinya. Sapi tersebut memberikan kontribusi yang cukup besar untuk kehidupan sosial ekonomi masyarakatnya karena kegiatan memelihara sapi sudah turun temurun, dengan tujuan kepemilikannya sebagai sumber pendapatan utama, sampingan dan tabungan. Selain itu keberadaannya berkontribusi terhadap pemenuhan kebutuhan daging sapi, khususnya di wilayah Ciamis dan sekitarnya. Sapi lokal tersebut memiliki proporsi tubuh yang relatif kecil karena telah beradaptasi terhadap lingkungannya dengan sarana produksi yang terbatas, termasuk ketersediaan pakan.
Langkah awal pemanfaatan sumber daya genetik adalah karakterisasi fenotipe berdasarkan sifat kualitatif dan kuantitatifnya. Sifat kualitatif adalah sifatsifat yang umumnya dijelaskan dengan katakata atau gambar, misalnya warna bulu, ada tidaknya tanduk, leher bergelambir atau tidak, yang dapat dibedakan tanpa harus mengukurnya, sifat ini biasanya hanya dikontrol oleh sepasang gen dan tidak dipengaruhi oleh faktor lingkungan. Sementara itu sifat kuantitatif seperti ukuran tubuh dan produktivitas adalah sifat-sifat yang dapat diukur, berupa nilai kontinue, dikendalikan oleh banyak pasang gen dan dipengaruhi oleh lingkungan ( Bourdon 1997; Noor 2008).

Sifat kualitatif dibandingkan dengan sifat kuantitatif umumnya kurang bernilai ekonomis, namun dalam beberapa hal 
menjadi penting, diantaranya pada saat hari raya Idul Adha, nilai jual sapi Peranakan Ongole lebih tinggi karena konsumen hewan kurban lebih menyukai warna sapi yang putih. Sifat kuantitatif ukuran tubuh, selain dapat digunakan untuk analisis keragaman populasi dan analisis silsilah, lebih bernilai ekonomis karena berimplikasi terhadap besaran proporsi tubuh. Informasi sifat kualitatif dan kuantitatif sapi Rancah tersebut masih terbatas. Penelitian ini bertujuan untuk mengidentifikasi warna bulu dan ukuranukuran tubuh sapi Rancah, sebagai upaya karakterisasi sapi lokal tersebut yang dapat dimanfaatkan sebagai informasi dasar untuk karakterisasi fenotip, pengelolaan dan pemanfaatannya.

Materi

Sampel penelitian untuk identifikasi sifat kualitatif dan kuantitatif adalah 92 ekor sapi Rancah betina, umur $>3$ tahun, masing masing 40 ekor dari kecamatan Tambaksari dan 52 ekor dari kecamatan Cijulang.

\section{Metoda penelitian}

Penentuan daerah penelitian dilakukan dengan metode purposive sampling, dengan kriteria daerah dengan populasi sapi Rancah tertinggi, dengan ketinggian tempat yang berbeda di kabupaten Ciamis, yaitu Tambaksari ( $\pm 500 \mathrm{dpl}$ ) dan Cijulang ( \pm 317 dpl), sedangkan penentuan sampel ternak dengan penarikan otoritas. Parameter yang diukur adalah : Warna bulu tubuh, Bobot badan, Panjang Badan, Tinggi pundak, Tinggi panggul, Lingkar dada, Lebar dada, Dalam dada, Panjang kepala dan Lebar kepala

\section{Analisis Data}

Karakteristik sifat kualitatif dan kuantitatif dianalisis secara deskriptif, perbedaan parameter bobot badan dan ukuran tubuh pada kedua populasi penelitian dianalisis dengan Uji T.

\section{HASIL DAN PEMBAHASAN}

\section{Karakteristik Warna Bulu}

Introduksi IB dengan sapi eksotik yang intensif, mengubah pola pemeliharaan sapi Rancah, yaitu peternak memelihara sapi lokal sebagai indukan untuk IB, sehingga di lapangan tidak ditemukan sapi jantan dewasa, sehingga identifikasi warna bulu hanya dilakukan pada sapi betina dewasa. Warna bulu yang ditemukan pada sapi lokal Ciamis betina dapat dikelompokkan menjadi 8 warna, yaitu coklat kehitaman, merah kecoklatan, coklat muda, putih kecoklatan (pisistan), abu-abu, putih, hitam, dan bercak coklat putih. Adapun distribusinya ditampilkan pada Tabel 1.

Hasil penelitian menunjukkan warna bulu dominan dengan frekuensi tertinggi di kedua daerah penelitian adalah merah kecoklatan, diikuti oleh warna coklat muda di Tambaksari dan warna putih kecoklatan (pisitan) di Cijulang (Tabel 1). Hasil penelitian ini sejalan dengan beberapa hasil penelitian warna bulu pada sapi lokal Indonesia yang menunjukkan warna bulu dominan adalah merah kecoklatan (merah bata/coklat kemerahan). Pada sapi Aceh betina, Abdullah (2008) menyatakan warna dominan sapi tersebut adalah merah bata sebesar $33.75 \%$ diikuti coklat muda 31\%. Penelitian Sarbaini (2004) mengemukakan warna dominan sapi Pesisir Sumatra Barat adalah merah bata (34.36\%), diikuti warna kuning $(25.51 \%)$. Selanjutnya Utomo et al. (2012) mengemukakan warna dominan pada sapi Katingan betina adalah coklat kemerahan sebesar $27 \%$, diikuti oleh warna coklat muda $(14.1 \%)$ dan coklat sapi Bali $(13.8 \%)$. 
Tabel 1. Sebaran warna bulu sapi Rancah di Ciamis

\begin{tabular}{|c|c|c|c|c|c|}
\hline \multirow[b]{2}{*}{ No } & \multirow[b]{2}{*}{ Uraian } & \multicolumn{2}{|c|}{ Tambaksari } & \multicolumn{2}{|c|}{ Cijulang } \\
\hline & & $\begin{array}{c}\text { Jumlah } \\
\text { (ekor) }\end{array}$ & $\begin{array}{c}\text { Frekuensi } \\
(\%)\end{array}$ & $\begin{array}{c}\text { Jumlah } \\
\text { (ekor) }\end{array}$ & $\begin{array}{c}\text { Frekuensi } \\
(\%)\end{array}$ \\
\hline 1. & Coklat kehitaman & 2 & 4.76 & 2 & 3.84 \\
\hline 2. & Merah kecoklatan & 19 & 45.24 & 25 & 48.08 \\
\hline 3. & Coklat muda & 6 & 14.29 & 4 & 7.69 \\
\hline 4. & Putih kecoklatan (Pisitan) & 4 & 9.58 & 11 & 21.15 \\
\hline 5. & Abu-abu & 2 & 4.76 & 2 & 3.85 \\
\hline 6. & Putih & 5 & 11.91 & 8 & 15.38 \\
\hline 7. & Hitam & 3 & 7.14 & - & - \\
\hline 8 & Bercak coklat putih & 1 & 2.38 & - & - \\
\hline
\end{tabular}

Warna bulu pada sapi ditentukan oleh ada tidaknya melanin, yang terbagi atas dua kelompok warna, yaitu eumelanin yang menentukan warna hitam atau coklat dan phaeomelanin yang menentukan warna merah, coklat kemerahan, tan dan kuning (Olson 1999; Klungland et al. 1995; Gil et al. 2007). Regulator utama untuk tata warna bulu tubuh pada sapi adalah gen Melanocortin Receptor 1 (MC1R/melanocyte stimulating hormone receptor). Variasi alel $M C 1-R$ diantara bangsa sapi menghasilkan perbedaan warna bulu (Klungland et al. 2008). Lokus $M C 1-R$ atau Extension locus (E) terdiri dari tiga alel, $\mathrm{E}^{\mathrm{D}}$ untuk hitam dominan, $\mathrm{E}^{+}$alel tipe liar yang bertanggung jawab terhadap warna coklat kemerahan dengan variasi warna hitam (kepala, leher, kaki, bagian belakang dan ekor) dan tipe e resesif untuk warna merah, dengan tingkat dominasi $\mathrm{E}^{\mathrm{D}}>\mathrm{E}^{+}>\mathrm{e}$. Lokus $\mathrm{E}$ mengatur produksi tirosinase, jika produksi tirosinase rendah akan menghasilkan pigmen phaeomelanin (merah/ee) dan sebaliknya jika produksi tirosinase tinggi akan menghasilkan pigmen eumelanin (hitam/ $\mathrm{E}^{\mathrm{D}}$ ) (Olson 1999). Warna lain pada sapi adalah hasil modifikasi sederhana dari tiga warna dasar yaitu hitam $\left(\mathrm{E}^{\mathrm{D}}\right)$, tipe liar (coklat-merahhitam) $\left(\mathrm{E}^{+}\right)$dan merah (ee). Variasinya disebabkan karena pengaruh gen/lokus lain yang terlibat mengontrol warna bulu, dengan pengaruh lightening atau menghapus warna. Gen lain yang terlibat dalam warna bulu adalah lokus A (agouti), BR (brindle), TYR dengan lokus $\mathrm{C}$ (albino), D (dilution), dn (dun) dan S, R, Bl (spotted) (Olson 1999). Paling tidak ada tujuh lokus yang terlibat dalam pengaturan warna bulu (Kantanen et al. 2000).

Warna dominan merah kecoklatan pada sapi lokal Ciamis betina diduga dipengaruhi oleh lokus $\mathrm{E}^{\mathrm{e}} \mathrm{E}^{\mathrm{e}}$ (ee) yang bersifat resesif terhadap $\mathrm{E}^{\mathrm{D}}$ dan $\mathrm{E}^{+}$. Hasil penelitian Utomo et al. (2012 ) pada sapi Katingan betina, menduga bahwa warna dominan coklat kemerahan diatur oleh gen resesif ee. Selanjutnya Kantanen et al. (2000) mengemukakan bahwa pada sapi Nordic ditemukan lokus $\mathrm{E}^{\mathrm{e}}$ jika resesif $\mathrm{E}^{\mathrm{e}} \mathrm{E}^{\mathrm{e}}$ menghasilkan warna merah. Variasi warna merah kecoklatan pada sapi Rancah Ciamis, yaitu warna coklat muda dan putih kecoklatan (pisitan) diduga dipengaruhi oleh lokus D (dilution), lokus Dun (dn) atau Agouti ( $\left.\mathrm{a}^{\mathrm{i}} \mathrm{a}^{\mathrm{w}}\right)$. Olson (1999) mengemukakan bahwa variasi warna merah terang pada sapi Simental disebabkan oleh adanya gen dilusi pada kondisi heterozigot (eeDsds), sedangkan kuning terang/tan dipengaruhi gen dilusi dalam keadaan homozigot (eeDsDs). Selanjutnya Olson (1999) menyatakan bahwa ternak dengan warna bulu krem, seperti halnya pada program crossbreeding Brahman dan Brown Swiss dengan Red Angus, mungkin merupakan hasil kombinasi heterozigot lokus Agouti $\mathrm{a}^{\mathrm{i}}$ atau $\mathrm{a}^{\mathrm{w}}$ dengan $\mathrm{dn}$ (Dun).

Pada populasi sapi lokal betina di Tambaksari ditemukan warna bulu hitam 
(7.14\%), diduga warna ini dipengaruhi oleh alel dominan $\mathrm{E}^{\mathrm{D}}$, Sedangkan variasi warna abu-abu dipengaruhi oleh gen $\mathrm{E}^{\mathrm{D}}$ dan $\mathrm{D}$ (dilusi) yang bersifat dominan $\left(\mathrm{E}^{\mathrm{D}} / \mathrm{D}_{-}\right)$. Frekuensi warna putih pada populasi Cijulang cukup tinggi (15.38\%), warna ini diduga dipenngaruhi oleh alel $\mathrm{E}^{+}$, lokus $\mathrm{Br}$ (brindel) dan lokus Agouti. Olson (1999) mengemukakan bahwa eumelanin (hitam) dibatasi oleh gen $\mathrm{Br}$ (brindel) dan warna merah dihapus oleh lokus dn dan bekerja bersama dengan lokus Agouti $\left(\mathrm{a}^{\mathrm{i}}\right.$ atau $\left.\mathrm{a}^{\mathrm{w}}\right)$, dapat menghasilkan warna putih.

\section{Ukuran Ukuran Tubuh}

Rataan bobot badan dan ukuran-ukuran tubuh sapi lokal Ciamis disajikan pada Tabel 2.

Tabel 2. Rataan bobot badan dan ukuran-ukuran tubuh sapi Rancah di Ciamis

\begin{tabular}{|c|c|c|c|c|c|c|}
\hline \multirow[t]{3}{*}{ Parameter } & \multicolumn{2}{|c|}{ Tambaksari } & \multicolumn{2}{|l|}{ Cijulang } & \multicolumn{2}{|c|}{ Rataan Populasi } \\
\hline & Rataan \pm sd & KK & Rataan \pm sd & KK & Rataan \pm sd & KK \\
\hline & $(\mathrm{cm})$ & $(\%)$ & $(\mathrm{cm})$ & $(\%)$ & $(\mathrm{cm})$ & $(\%)$ \\
\hline Bobot badan (kg) & $257.32^{\mathrm{a}} \pm 35.44$ & 13.77 & $275.64^{b} \pm 34.36$ & 12.46 & $267.68 \pm 35.81$ & 13.38 \\
\hline P. badan $(\mathrm{cm})$ & $121.95^{\mathrm{a}} \pm 5.94$ & 4.87 & $124.73^{b} \pm 6.56$ & 5.26 & $123.52 \pm 6.42$ & 5.19 \\
\hline T. pundak $(\mathrm{cm})$ & $114.10^{\mathrm{a}} \pm 3.86$ & 3.38 & $116.06^{\mathrm{b}} \pm 4.60$ & 3.96 & $115.21 \pm 4.38$ & 3.80 \\
\hline T. panggul $(\mathrm{cm})$ & $118.24^{\mathrm{a}} \pm 4.37$ & 3.69 & $120.56^{\mathrm{b}} \pm 4.99$ & 4.14 & $119.55 \pm 4.85$ & 4.05 \\
\hline Lkr. dada $(\mathrm{cm})$ & $150.59^{a} \pm 7.60$ & 5.05 & $154.16^{\mathrm{b}} \pm 6.63$ & 4.30 & $152.61 \pm 7.25$ & 4.75 \\
\hline Lbr dada (cm) & $25.23^{\mathrm{a}} \pm 3.26$ & 12.93 & $29.33^{b} \pm 2.56$ & 8.72 & $27.55 \pm 3.52$ & 12.79 \\
\hline Dlm dada (cm) & $53.30^{\mathrm{a}} \pm 5.16$ & 9.67 & $55.78^{b} \pm 3.37$ & 6.04 & $54.70 \pm 4.39$ & 8.03 \\
\hline P. Kepala (cm) & $40.99^{\mathrm{a}} \pm 2.10$ & 5.11 & $41.46^{\mathrm{a}} \pm 2.84$ & 6.85 & $41.26 \pm 2.54$ & 6.16 \\
\hline Lbr Kepala (cm) & $17.33^{\mathrm{a}} \pm 1.15$ & 6.66 & $17.58^{\mathrm{a}} \pm 1.45$ & 8.25 & $17.48 \pm 1.33$ & 7.62 \\
\hline
\end{tabular}

eterangan : $\mathrm{sd}=$ standar deviasi; $\mathrm{KK}=$ koefisien keragaman; $\mathrm{P}=$ panjang, $\mathrm{T}=$ Tinggi; $\mathrm{Lkr}=$ lingkar $; \mathrm{Lbr}=$ lebar; $\mathrm{Dlm}=$ dalam. Huruf yang berbeda pada baris yang sama menunjukkan berbeda nyata $(\mathrm{P}<0.05)$

Keragaman bobot badan baik di Tambaksari maupun di Cijulang cukup tinggi, masing-masing sebesar $13.77 \%$ dan $12,46 \%$, hal ini diduga bobot badan merupakan parameter kuantitatif yang sangat dipengaruhi oleh lingkungan, termasuk tatalaksana pemeliharaan dan pemberian pakan. Kondisi dilapangan menunjukkan ada dua sistem pemeliharaan, yaitu petani yang tidak memiliki sawah atau ladang, sapinya dikandangkan sepanjang hari, sedangkan jika petani memiliki sawah dan ladang, siang hari sapi digembalakan di kedua tempat tersebut dan malam dikandangkan serta masih diberikan rumput.

Keragaman ukuran tubuh di kedua daerah penelitian relatif rendah, kecuali lebar dada. Hal ini disebabkan ukuran tubuh yang diidentifikasi diperoleh dari sapi dewasa yang sudah tidak mengalami pertumbuhan lagi, dan pengukuran ukuran tubuh cenderung mengukur kerangka tubuh. Kerangka tubuh berkaitan dengan pertumbuhan tulang, Aberle et al. (2001) menyatakan bahwa pada umur penggemukan sekitar 2-3 tahun tingkat pertumbuhan tulang sudah mulai menurun, dan proses selanjutnya adalah peningkatan bobot daging dan lemak.

Hasil analisis menunjukkan rataan bobot badan dan ukuran-ukuran tubuh kecuali panjang kepala dan lebar kepala di Cijulang nyata lebih tinggi $(\mathrm{P}<0,05)$. dibandingkan dengan di Tambaksari. Hal ini diduga karena introgasi sapi PO di daerah ini lebih intensif. Pada tahun 2000 - 2005 Pemda Jawa Barat membangun pusat pembibitan sapi potong di Cijayana yang berada di pesisir pantai selatan Jawa Barat berdekatan dengan Cijulang. Program ini diadakan dengan tujuan untuk pemberdayaan 
sapi potong di daerah kaki gunung Cikuray, Papandayan, Malabar dan Patuha (Cipamatuh), bibitnya adalah sapi PO

Tabel 3. Rataan bobot badan dan ukuran tubuh beberapa sapi betina lokal Indonesia

\begin{tabular}{lccccc}
\hline \multicolumn{1}{c}{ Parameter } & PO & Bali & Aceh & Katingan & Rancah \\
\hline Bobot badan $(\mathrm{kg})$ & $296.40 \pm 48.23$ & $198.21 \pm 38.04$ & $161.19 \pm 23.28$ & $209.27 \pm 23.63$ & $267.68 \pm 35.81$ \\
P. badan $(\mathrm{cm})$ & $128.10 \pm 6.77$ & $113.06 \pm 3.48$ & $103.95 \pm 6.98$ & $115.96 \pm 6.23$ & $123.52 \pm 6.42$ \\
T. pundak $(\mathrm{cm})$ & $123.00 \pm 6.30$ & $110.00 \pm 4.24$ & $99.32 \pm 4.59$ & $102.63 \pm 4.90$ & $115.21 \pm 4.38$ \\
T. panggul $(\mathrm{cm})$ & $131.20 \pm 7.27$ & $109.89 \pm 4.06$ & $103.85 \pm 4.25$ & $105.90 \pm 4.37$ & $119.55 \pm 4.85$ \\
Lkr dada $(\mathrm{cm})$ & $154.93 \pm 9.80$ & $150.91 \pm 8.53$ & $129.09 \pm 6.62$ & $139.43 \pm 6.47$ & $152.61 \pm 7.25$ \\
Lbr dada $(\mathrm{cm})$ & $30.77 \pm 2.70$ & $28.80 \pm 3.20$ & $24.49 \pm 3.99$ & $26.90 \pm 3.50$ & $27.55 \pm 3.52$ \\
Dlm dada $(\mathrm{cm})$ & $56.53 \pm 3.63$ & $60.10 \pm 3.30$ & $45.68 \pm 5.90$ & $50.06 \pm 3.83$ & $54.70 \pm 4.39$ \\
P. Kepala $(\mathrm{cm})$ & $46.23 \pm 2.83$ & $40.80 \pm 1.80$ & $38.89 \pm 2.44$ & $38.67 \pm 2.57$ & $41.26 \pm 2.54$ \\
Lbr Kpl $(\mathrm{cm})$ & $20.37 \pm 1.27$ & $14.00 \pm 0.60$ & $18.10 \pm 1.57$ & $17.73 \pm 1.33$ & $17.48 \pm 1.33$ \\
\hline
\end{tabular}

Sumber : Sapi PO (Hartati et al. 2010); Bali (Tonbesi et al. 2010 dan Otsuko et al. 1980.; Aceh (Abdullah 2008); Katingan (Utomo et al. 2010). $\mathrm{sd}=$ standar deviasi; $\mathrm{KK}=$ koefisien keragaman; $\mathrm{p}=$ panjang, $\mathrm{T}=$ Tinggi; $\mathrm{Lkr}=$ lingkar $; \mathrm{Lbr}=$ lebar; $\mathrm{Dlm}=$ dalam; $\mathrm{Kpl}=$ kepala

Bobot badan dan morfometrik sapi Rancah lebih besar dibandingkan dengan sapi Aceh dan Katingan, dan hampir sama dengan sapi Bali kecuali bobot badan, panjang badan dan tinggi panggulnya relatif lebih besar serta kepalanya lebih panjang. Apabila dibandingkan dengan sapi PO bobot badan dan ukuran tubuhnya lebih kecil (Tabel 3). Berdasarkan hal tersebut bobot badan dan morfometrik sapi lokal Ciamis berada diantara sapi Bali dan sapi PO. Hal ini diduga bahwa sapi lokal tersebut merupakan hasil persilangan sapi lokal setempat yang merupakan keturunan dari sapi Bali dengan sapi PO, hasil dari program Ongolisasi di Indonesia

\section{KESIMPULAN}

Warna bulu dominan sapi Rancah adalah merah bata. Bobot badan dan ukuran tubuh di Cijulang lebih besar dibandingkan dengan Tambaksari.kecuali panjang dan lebar kepala sama. Bobot badan dan ukuran tubuh sapi Rancah berada diantara sapi Bali dan PO.

\section{DAFTAR PUSTAKA}

Abdullah MAN, Noor RR, Martojo $H$, Solihin DD. 2008. Karakterisasi sapi Aceh dengan menggunakan DNA mikrosatelite. JITAA. 33(3):165-175

Aberle DE, Forrest JC, Gerrard DE, Milles EW. 2001. Principles of Meat Science. $4^{\text {th }}$ edition San Francisco (US). W.H. Freeman and Company.

Bourdon RM. 1997, Understanding of Animal Breeding. New Jersey (US): Prentice Hall.

Hartati, Sumadi, Subandriyo and Hartatik T.. 2010. Morphological diversity and genetic differentiation of PO cattle in smallholder farmers. JITV 15(1):7280 . 
Kantanen J. Olsaker I, Brusgaard K, Eythorsdottir E, Holm LE, Lien S, Danell B and Adalsteinsson S. 2000. Frequencies of genes for coat colour and horns in Nordic cattle breeds. Genet. Sel. Evol. 32:561-576.

Klungland, H., DI. Vage, L. Gomez-Raya, S. Adalsteinsson and S. LIEN. 1995. The role of melanocyte-stimulating hormone $(\mathrm{MSH})$ receptor in bovine coat color determination. (Abstract). Mamm. Genome 6: 636.

Noor, R.R. 2008. Genetika Ternak. Depok (ID). PT. Penebar Swadaya.

Olson TA. 1999. Genetic of colour variation. Di dalam; Fries $\mathrm{R}$ and Ruvinsky ,Editor. The Genetics of Cattle. New York (US). CAB International p 33-53.

Otsuka J. Kondo K, Simamora S. Mansjoer SS and Martojo H. 1980. Body measurments of Indonesian native cattle. Di dalam: Report research. The origin and phylogeny of Indonesian native livestock investigation on the cattle, fowl, and their wild forms. The research Group of Overseas Scientific Survey: 7-18

Sarbaini. 2004. Kajian Keragaman Karakter Eksternal dan DNA Mikrosatelit Sapi Pesisir di Sumatra Barat [disertasi]. Bogor (ID) : Institut Pertanian Bogor.

Tonbesi, TT, Ngadiyono N dan Sumadi. 2009. Estimasi potensi dan kinerja sapi bali di kabupaten Timor Tengah Utara, propinsi Nusa Tenggara Timur. Buletin Peternakan 33(1): 30-39.

Utomo BN, Noor RR, Sumantri C, Supriatna I dan Gurnadi E.. 2010. Keragaman morfometrik sapi Katingan di Kalimantan Tengah JITV. 15(3) : 220230

Utomo BN, Noor RR, Sumantri C, Supriatna I dan Gurnadi E..2012. Keragaman fenotipik kualitatif sapi Katingan. JITV 17(1): 1-12. 